\title{
Water Rights and Federalism - The Western Water Rights Settlement Bill of 1957
}

\author{
Charles E. Corker*
}

This article concerns two of the most difficult problems with which people in the United States nust live. One is water, the other is federalism. Both are the subjects of fiercely-held emotional attitudes.

The Civil War was fought over the problem of the proper relationship of federal and state governments. Today, after nearly a century and three quarters of government under the Constitution, and in the final decade of the century following the Civil War, relations between federal and state governments still present perplexing and unresolved problems-among them, taxation, commerce, judicial administration, and education. Not least of these problems is water.

Water, even uncomplicated by federalism, nurtures controversies which are both long and bitter. Ever since western water rights were first established in the mining camps of the Sierra Nevadas, it has frequently been nip and tuck whether differences of opinion would be resolved by briefs or by bullets. It is not remarkable, therefore, that the Barrett Bill, ${ }^{1}$ which attempts to define federal-state relationships in the matter of water rights, should have encountered heated controversy. It is the child, and not the parent, of a very long and often heated dispute, sometimes centered on matters of principle, sometimes on matters of administration.

The controversy is intense; it therefore should be made clear that the views expressed are personal to the writer. Since any response to the Barrett Bill is likely to be colored by one's attitude toward the more general problems inherent in federal-state relationships, candor compels something more by way of identification of the writer's personal point of view. The federal form of government, with powers vested in the people or the states except insofar as they are expressly or impliedly delegated to the United States, was originally a political compromise put together as a necessity for the survival of thirteen weak but fiercely independent nations. Whether by happy accident or by divine guidance, that government combines, better than any alternative that might be devised, state freedom to deal with state problems, and national freedom to deal with the nation's problems. Adjustment, compromise, and growth are an inherent part of what may be thought of as

* Member, California Bar; Deputy Attorney General, State of California, assigned to the pending Colorado River litigation, Arizona v. California, No. 10 original, October 1957 Term.

1 Originally S. 863, 84th Cong., 1st Sess. (1955), included as Appendix I; for the version pending in the present Congress, also labelled S. 863, see Appendix II. 
not so much a federal system as a federal process. In the sense that federalism is a process, its problems will never be finally "solved."

Justification of the federal form of government is as unnecessary as justification of the use of water. However, realization that the federal system gives rise to many problems to which there is no easy solution may help us seek to resolve the problems with which the Barrett Bill deals in the spirit of 1787 rather than the spirit of Fort Sumter.

Water controversies are long and bitter for a number of reasons; these are important to understand. First, because loss of a right to use water in many parts of the United States leaves land without value, the stakes are high. People defend their water rights as they defend their homes. Second, under any system of water rights there are disappointed expectations, partly from over-optimism in predicting supply and partly from an inability to predict requirements. Third, for states as well as for lesser poitical umits, projects, and individuals, part or all of the source of the water is usually outside the jurisdiction, control, or ownership of the water user. Fourth, there are inany conflicting interests which compete for an inadequate supply. Uses for irrigation and for cities require full reservoirs; flood control requires empty reservoirs. Power users want water released at times of maximum power demand, and these times do not coincide with maximum needs of water for irrigation and domestic use. Fish and wild life areas evaporate water from swamps and lagoons which irrigators and cities would drain and put into ditches or aqueducts. Salmon cannot swin upstream through spinning turbines. These are only examples of conflicts which become increasingly critical as we approach closer to the limits of water supply.

The fundamental problem posed by the Barrett Bill can be simply stated: At what level of government are these conflicts to be resolved-in local communities, in state capitals, in Congress, in executive departments of the United States Government, in the Supreme Court of the United States, in compact negotiations between states subject under the Constitution to congressional consent, or somewhere else? The inere statement of the issue makes it apparent that a categorical and unequivocal answer cannot be expected from the Barrett Bill or from any other proposal likely to be advanced.

Any consideration of the Barrett Bill should begin with its text. Two versions of the Bill, both bearing the number S. 863, are included as appendices. The first, and shorter version was introduced by Senator Frank Barrett of Wyoming for himself and seven other Senators in the 84th Congress on February 1, 1955. In its fully elaborated form it was reintroduced by

2101 CoNG. Rec. 1019 (1955). 
Senator Barrett for himself and fifteen other Senators in the 85th Congress on January $25,1957 .^{3}$

The original Barrett Bill is included as Appendix I because, being shorter, it gives a somewhat clearer notion of what the sponsors are trying to accomplisl. The current bill, except for a long preamble in section 2, adds principally some provisos designed to disarin the bill's opponents, and some strengthening langnage designed to say, for the Congress, "and we really mean it."

The central theme of both bills can be reduced to a few words: All unappropriated water in the seventeen western states is declared to be free for appropriation under state law. It is the purpose here to consider that objective, avoiding as much as possible quibbles over draftsmanship.

\section{I}

\section{OBJECTIVES AND ANALYSIS}

The first question to be asked with respect to any proposed legislation is, what problem is it designed to solve? Most legislation is designed to bring about changes in the law; some legislation is designed merely to remove uncertainty. The Barrett Bill combines these two purposes. ${ }^{4}$

Without oversimplifying more than is permissible, the objectives of the Barrett Bill can be described as an effort to reverse the result of two recent judicial decisions, and the possible result in a third case now pending in Nevada. The analysis of the Barrett Bill will center on those cases.

The first is FPC v. Oregon ${ }^{5}$ - the so-called Pelton Dam case. It involves a conflict between the Federal Power Commission and the State of Oregon on the Deschutes River, which the Court in that case held to be nonnavigable. The second is Washington Department of Game v. FPC, involving the navigable water of the Cowlitz River in Washington. The third case, still pending, is Nevada ex rel. Shamberger, State Engineer v. United States, and involves a conflict between Nevada and the Navy Department over underground water underlying the Hawthorne Naval Ammumition Depot. ${ }^{7}$

3103 Cong. REc. 846 (Daily ed. Jan. 25, 1957). Legislation, some of it in identical form, was also introduced and considered by the House in the 34th Congress. For texts see Hearings on H.R. 8325, H.R. 8347, H.R. 8560, and H.R.9505 Before the House Committee on Interior and Insular Affairs, 84th Cong., 2d Sess., ser. 31 (1956).

4 "The law" is a phrase used here in reference to what courts do. Barrett Bill supporters have emphasized that the Barrett Bill is declaratory of "the law," meaning what Congress, by statutes heretofore enacted, intended to have the courts do. See Hearings on S. 863 Before the Subcommittee on Irrigation and Reclamation of the Senate Committee on Interior and Insular Affairs, 84th Cong., 2d Sess. 248 (1956).

5349 U.S. 435 (1955).

( 207 F.2d 391 (9th Cir. 1953), cert. denied, 347 U.S. 936 (1954).

7 The selection of recent cases makes a cavent necessary. The Barrett Bill problem did not arise yesterday. The reader should see Bannister, The Question of Federal Disposition of State Waters in the Priority States, 28 FARv. L. REv. 270 (1915) ; Munro, The Pelton Decision: A 


\section{A.The Pelton Dam Case-Nonnavigable Water}

Most discussions of the Barrett Bill start with FPC v. Oregon, ${ }^{8}$ the now celebrated Pelton Dam case. In fact, the case was decided on June 6, 1955, over four months after the original Barrett Bill had been introduced. While the bill has picked up a net total of eight additional senatorial sponsors since the Court's decision, it is important to recall that the problem began before-long before-the Supreme Court reversed the Court of Appeals for the Ninth Circuit.

The result of the Pelton Dam case can be easily stated. The Court held that the Federal Power Commission may license a private hydroelectric power project at the Pelton Dam site on the nonnavigable Deschutes River in Oregon, notwithstanding the objections of the State of Oregon that the dam would interfere with anadromous fish and was contrary to the laws of that state. ${ }^{9}$ The decision was seven to one, Justice Douglas dissenting on non-constitutional grounds. As constitutional law, the case will continue to be the supreme law of the land until the Supreme Court changes its mind or the Constitution is amended. Neither possibility seems likely in the near future.

The decision was based on the fact that the dam was to be built on reserved federal lands, one end abutting on an Indian reservation, reserved for power purposes since 1910 and 1913, and the other on government lands

New Riparianism?, 36 ORE. L. REv. 221 (1957); Martz, The Role of the Federal Government in State Water Law, $5 \mathrm{KAN}$. L. REv. 626 (1957). The first is a careful exposition of the socalled California and Colorado doctrines, to which reference will be made in text at note 17 infra. Professor Munro's article is a detailed criticism of the Pelton Dam case for what he believes is a disregard of a century of developinent of western land and water law. Professor Martz reviews federal water resources development with a critical eye, concluding that the Barrett Bill should pass.

8349 U.S. 435 (1955). The Court reversed Oregon v. FPC, 211 F.2d 347 (9th Cir. 1954), which had set aside an order of the Federal Power Commission granting a hicense. For the Commission's decision and order, see Portland Gen. Elec. Co., 10 F.P.C. 445 (1951).

9 The Secretary of Agriculture had reported favorably on the license application to the Federal Power Commision. The Secretary of Interior had recommended to the Commission that the license be denied because of interference with the Lower Columbia Fisheries program which contemplated a greater use of the Deschutes as a fish propagation stream. Id. at 456-57.

Most of the criticism of the result has stemmed not from the damage to the fishing interests, but from the fact that the Federal Power Commission was permitted to deny to the State of Oregon a decision as to how its resources are to be used. The fish seem to have done rather well. The commission found that the reasonably estimated total annual cost of the power applicant's fish conservation program, including fixed charges on investment and operation and maintenance, was $\$ 795,000$. It also found that the annual value of anadromous fish produced above the Pelton dam site, as estimated by the Oregon Fish Commission, is $\$ 177,375$, imcluding $\$ 15,600$ attributable to recreation value resulting from sports fishing. Annual sports value of trout fishing to be lost in the area to be flooded by the dams was estimated at about $\$ 24,000$. Id. at 455 . These figures, of course, do not purport to appraise the injury to increased fish development which the opponents of the license alleged was contemplated. Id. at 446. 
withdrawn from entry and reserved for power purposes, in the Court's language, "at least since 1909."10

The reasoning is simple. Acts of Congress of July 26, 1866,11 July 9, $1870,{ }^{12}$ and the Desert Land Act of $1877^{13}$ severed rights in land from rights to use water with respect to the public lands of the United States, thereby permitting appropriations of water in accord with state law or custom. ${ }^{14}$ These acts do not, however, make this severance of land and water with respect to reserved lands withdrawn from entry.

What the Court did not decide is as significant as what it did decide. The license granted by the Federal Power Commission protected vested rights of appropriators, and hence the Court was not called upon to decide what the result would be had such rights not been recognized. ${ }^{15}$ Had there been interference with vested rights, the Court would perhaps have avoided a constitutional problem by holding that section 27 of the Federal Power

10349 U.S. at 439.

11 REV. STAT. § 2339 (1875), 30 U.S.C. \& 51 (1952).

12 REV. STAT. \$§ 2339, 2340 (1875), 43 U.S.C. §661 (1952).

1319 STAT. 377,43 U.S.C. \& 321 (1952).

14 The earliest Supreme Court recognition of the state or territorial law of prior appropriation, which Congress sanctioned by its early statutes, is found in three opinions by Justice Field: Atchison v. Peterson, 87 U.S. (20 Wall.) 507 (1874); Basey v. Gallagher, 87 U.S. (20 Wall.) 670 (1874) ; Jennison v. Kirk, 98 U.S. (8 Otto) 453 (1878). In Broder v. Natoma Water Co., 101 U.S. (11 Otto) 274 (1879), the Court held that rights recognizcd by the Act of 1866, REv. STAT. $\$ 2339$ (1875), 30 U.S.C. $\$ 51$ (1952), relate back to acquisition by possession prior to 1866. For a inodern exposition, see California Oregon Power Co. v. Beaver Portland Cement Co., 295 U.S. 142 (1935).

15 Article 28 of the FPC's license provides:

"Any rights to the use of waters in the Deschutes River and its tributaries in connection with the licensee's project under this license sliall be subordinate to:

"(i) All existing rights, whether or not perfected, to the waters of the Deschutes River and its tributaries for domestic, stock, municipal and irrigation purposes, including the right to store any such waters in the proposed Benham Falls, Post and Prineville reservoirs and in the existing Crane Prairie, Crescent Lake, and Wickiup reservoirs; and

"(ii) The use of additional flows of the Deschutes River and its tributaries pursuant to rights which may be initiated hereafter for the diversion and storage of waters for domestic, municipal, stock, and irrigation purposes in connection with any reclamation projects undertaken pursuant to the Federal Reelamation Laws (Act of June 17, 1902, 32 Stat. 388, and acts amendatory thereof or supplenientary thereto) the amounts of water to be used under the addltional rights, together with the uses under existing riglits whatever they may be, not, by reason of the additional right, to exceed these quantities:

"(a) Deschutes River and its tributaries above Cline Falls-entire flow; (b) Squaw Creek -all flows during the non-irrigation season; (c) Lake Creek-20,000 acre-feet annually; (d) Crooked River and its tributaries-all the flows above the Highway Bridge at the place where U.S. highway 97 crosses the Crooked River Canyon; (e) Crooked River below the Highway bridge not to exceed 2,500 acre-feet annually for the proposed Deschutes project doniestic water system; and (f) an additional 400 second feet that may be taken above the Licensee's project either from the Deschutes River below Cline Falls or the Crooked River below the highway bridge during the irrigating season." Portland Gen. Elec. Co., 10 F.P.C. 445, 458-59 (1951). 
Act ${ }^{16}$ protects them. Common sense demands that answer, but logically it raises difficuities, at least if "vested rights" is given its normal meaning.

Let us explore that problem. In the Pelton Dam case, the Court, without resort to the label, adhered to the so-called California doctrine of appropriative rights, as distinguished from the Colorado doctrine. ${ }^{17}$ Under the California doctrine, every appropriator traces title from the United States, acquiring his right by virtue of the Desert Land Act of $1877^{18}$ and related legislation, which severed water rights from the public lands. The Colorado doctrine, by contrast, holds that water rights in the west do not exist until rights are created by appropriation and use under the laws and customs of the west.

Under the California doctrine, the United States is originally possessed of a water right, riparian in nature, by reason of its ownership of the public domain. In the Pelton Dam case, the Federal Power Commission was held to have exercised that right. It would seem, however, that the United States could no more cut off an appropriator's vested right than it could cut off the right of a patentee of public land by revoking his patent.

But what is the appropriator's vested right? The public land withdrawals in the Pelton Dam case took place in 1909, 1910, and 1913. Under the Court's logic, whatever rights the United States liad were established as of one of those dates, perhaps the earliest. It would seein to be impossible for an appropriator after the withdrawal to acquire a right good against the federal right exercised by the Federal Power Commission in licensing the Pelton project. Otherwise, what was the significance, with respect to the use of the water, of the 1909,1910 , and 1913 dates of withdrawals of the dam site?

Mr. J. Lee Rankin, Assistant Attorney General of the United States, now Solicitor General, expressed his view to the House Interior and Insular Affairs Committee in 1956: ${ }^{10}$

As I understand the Pelton decision, any rights that are vested in accordance with and in compliance with the State laws up to the moment the United States takes any action toward its own purposes in regard to that water, are not affected in the least. It is only as to the unappropriated water where the right to the use of it has not vested that there is any effect of Peiton decision.

16 "Nothing contained in this chapter shall be construed as affecting or intending to affect or in any way to interfere with the laws of the respective States relating to the control, appropriation, use, or distribution of water used in irrigation or for municipal or other uses, or any vested right acquired therein." 41 STAT. 1077 (1920), 16 U.S.C. \$ 821 (1952).

17 These two doctrines are discussed in Bannister, The Question of Federal Disposition of State Waters in the Priority States, 28 HARv. L. REv. 270 (1915).

1819 STAT. 377 (1877), 43 U.S.C. \$ 321 (1952).

10 Hearings, supra note 3 , at 17. 
The difficulty is in fixing "the moment the United States takes any action toward its own purposes." Mr. Rankin apparently assumes that it was the moment when the Federal Power Commission licensed the project. Why not, however, 1909 when the United States reserved the power site? The Court's opinion points toward that as the noment when the United States first took action toward its purposes. Perhaps Mr. Rankin is right, but there is nothing in the Court's opinion, nor in the nature of the commonlaw riparian right, which supports his view.

A second question was left uncertain by the Court's decision. Can future appropriators for irrigation or domestic use prevail against the power project which the Federal Power Commission licensed? Must needed water pass to the Pacific to turn federally licensed generators? The license which the Court upheld seems to make it clear that the answer is yes. Article 28 of the hicense makes it subject to existing rights and to future rights where such future rights are initiated with respect to a project under the federal Reclamation Act, ${ }^{20}$ provided that the existing and future rights may not exceed a fixed ceiling. ${ }^{21}$ Since it does not appear that the Federal Power Commission's hicense was challenged on the ground that it limits future domestic and irrigation use, it is not clear whether future appropriators are forestalled from hereafter attacking this limitation in future litigation. It would seem, however, that if the United States has granted a vested right to a power company, neither the United States nor a state can destroy that right without meeting a due process objection. ${ }^{22}$

If it is true that the Federal Power Commission has dedicated unappropriated water to generation of power to the exclusion of domestic and irrigation use, a number of criticisms become germane. This flies in the face of the policy of numerous state and federal statutes ${ }^{23}$ which prefer consump-

2032 StaT. 388 (1902) (codified in scattered sections of 43 U.S.C.).

21 See note 15 supra, for text of art. 28 of the license.

$22 \mathrm{Mr}$. Willard Gatchell, General Counsel of the Federal Power Commission, made clear his view that the power company was accorded a vested right:

"Senator O'Maronex. Do you interpret this [the Pelton dam decision] to mean that the Federal Power Commission can issue licenses for the utilization of water which has not been determined to be navigable, in spite of the provisions of the law, and that the water thereby falls into the exclusive use of the licensee, regardless of what claims may afterward be made under State law for use of the water?

"In other words, does the Federal Power Act and this decision make water used for power under a Federal Power Commission license take priority over the use of water for agricultural, industrial, and mining purposes?

"Mr. Gatcereul. Yes. . .." Hearings, supra note 4, at 190.

23 See, e.g., Flood Control Act, 1944, § 1, 58 Stat. 887, 33 U.S.C. \$ 701-1(b) (1952), which declares, with respect to works therein authorized, that "The use for navigation ... of waters arising in States lying wholly or partly west of the ninety-eighth ineridian shall be only such use as does not conflict with any beneficial consumptive use, present or future, . . o of such waters for domestic, municipal, stock water, irrigation, mining, or industrial purposes."

Colorado River Storage Project Act \$ 7, 70 Star. 109 (1956), 43 U.S.C. § 620f (Supp. IV 
tive-irrigation and domestic-uses to other uses. These statutes are based on the recognition that there are substitutes for hydroelectric energy but not for water applied to consumptive use. Moreover, the Federal Power Commission is thrust into the business of making determinations of future water requirements in direct conflict with state agencies better equipped to make those determinations. Finally, the Pelton license protects, to a limited extent, future rights for reclamation projects, but does not protect in any degree private or non-federal future projects not under jurisdiction of the Bureau of Reclamation. ${ }^{24}$ For such discrimination no justification can be found.

1956) provides: ". . Subject to the provisions of the Colorado River Compact, neither the impounding nor the use of water for the generation of power and energy at the plants of the Colorado River storage project shall preclude or impair the appropriation of water for domestic or agricultural purposes pursuant to apphicable State law."

Section TV(b) of the Colorado River Compact provides: "Subject to the provisions of this compact, water of the Colorado River System may be impounded and used for the generation of electrical power, but such impounding and use shall be subservient to the use and consumption of such water for agricultural and domestic purposes and shall not interfere with or prevent use for such dominant purposes." The text of the compact appears in Wilbur and Ely, Hoover Dam Docunerts, H.R. Doc. No. 717, 80th Cong., 2d Sess., p. Al7 (1948).

ORE. REv. STAT. \$ 536.310(12) (1955) prescribes the following policy for the State Water Resources Board: "When proposed uses of water are in mutually exclusive conflict or when available supphes of water are insufficient for all who desire to use them, preference shall be given to human consumption purposes over all other uses and for livestock consumption, over any other use, and thereafter other beneficial purposes in such order as may be in the public interest consistent with the principles of this Act under the existing circumstances."

$I d . \$ 536.340$ (3) provides that the Board "may, subject to existing rights and priorities and subject to the preferential uses named in subsection (12) of ORS 536.310, prescribe preferences for the future for particular uses of the waters of any lake, stream or other source of supply in aid of the highest and best beneficial use thereof; and in so doing it shall give effect and due regard to the natural characteristics of such streams or other sources of supply, the adjacent topography, the economy of such streams or other sources of supply, the economy of the affected area, seasonal requirements of various users of said water, the type of proposed use as between consumptive and nonconsumptive uses, and other pertinent data." (Emphasis added.)

Coro. Const. art. XVI, § 6 provides: "The right to divert the unappropriated waters of any natural stream to beneficial uses shall never be denied. Priority of appropriation shall give the better right as between those using the water for the same purpose; but when the waters of any natural stream are not sufficient for the service of all those desiring the use of the same, those using the water for domestic purposes shall have the preference over those claiming for any other purpose, and those using the water for agricultural purposes shall have preference over those using the same for manufacturing purposes."

The terms and legal effect of the provisions, of which the foregoing are examples, vary. So far as is known, however, power is nowhere in the west preferred to cousumptive use.

24 "According to the way I read this article, any new appropriation of water not made in connection with a reclannation project would conflict with Article 28. There are some such potential future uses. They will include private irrigation schemes, municipal water supplies and water for industrial purposes." Letter from Lewis A. Stanley, Oregon State Engineer, to the writer, August 27, 1957. For a description of the Deschutes River basin and its adjudicated water uses see In re Water Rights of Deschutes River and Its Tributaries, 134 Ore. 623, 286 Pac. 563, 294 Pac. 1049 (1930), and 148 Ore. 389, 36 P.2d 585 (1934). 
A third question which the Pelton Dam case leaves unanswered is whether the United States can acquire a site by purchase or condemnation and through ownership of the land acquire the rights the Court allowed it to exercise in that case. ${ }^{25}$ In other words, is the Pelton Dam decision limited to public lands held as part of the original public domain? Clearly it is so limited with reference to private projects merely licensed by the government, but what of projects where the government takes title?

The logic of the decision would uphold the federal right. If the United States has riparian rights as owner of the public domain in a state which recognizes no riparian rights, why does not the riparian right attacl when the government buys or condemns land? Vested rights that attached before the government acquired the land would, of course, be constitutionally protected, but as to unappropriated water there seems to be no basis for a distinction between original ownership by the government and acquired ownership. ${ }^{26}$ Resolution of this question is as important to the eastern states, without public lands, as it is to the west.

25 In fact, part of the Pelton installation, a reregulating dam, is to be located on private land to be acquired by the licensees. Since this dam was not the subject of complaint with respect to fish, the Court found it unnecessary to deal witl the problem of acquired land. 349 U.S. at 439.

26 "Senator KuCHEI. Assume that the Federal Government acquires property by purchase, are its rigbts to water for that property, in your opinion, any greater than those of a private landowner who owns property in that same area?

"Mr. RANriv. The only difficulty in [sic] that to say 'yes' or 'no' is tha [sic] the United States under the Constitution has greater rights than the private owner by cession from the States. Oftentimes Congress has provided for the acquisition by condemnation of military lands or other reservations and then the Government has asked, through the various departments involved, whether or not the State would cede jurisdiction over those lands. In many instances, every right of jurisdiction has been ceded except the right of taxation. There have been some rights of taxation that have been reserved in soine cases.

"The courts have held that in view of the Constitution in those cases the United States has complete jurisdiction to make the laws for that area and that takes it out of a class just like the State is out of a class of the ordinary property owner who is a citizen.

"Senator KuCHeL. So your answer would be that it is impossible to say that the Federal Government, when it hereafter acquires a piece of property, can have its water rights measured in exactly the same fashion that a private landowner would have them measured.

"Mr. RANRIN. That is true.

"Senator KUCHEL. If the Congress desired to adopt the policy that the Federal Government hereafter would, when it acquired property in a State, submit to the jurisdiction of the State with respect to rights of water in the same fashion as a private landowner, would there be any constitutional objection to that, in your opinion?

"Mr. RaNkIN. Yes. Because you are saying as to Federal property the Federal Government shall be subordinate to a State. The Constitution says the Federal Government, when it is exercismg its proper powers, cannot be subordinate to the State. It seems to me tbat Congress could resolve this problem so far as that particular part is coneerned. I don't menn that is the solution for the whole problem. It could resolve that by saying it is desirable as a policy in order to have a proper record that the Government file in the States its claims in regard to a particular natter, but to say that the State could deny the Federal Government the power to have a well or some other proper activity under the Constitution would be subordinating tbe Federal Government again to State control. 
The Court's opinion in the Pelton Dam case leaves in doubt whether its choice of the California doctrine was consciously made with an awareness of the alternatives. Certainly there is no mdication of any recognition of the problems created for the federal judiciary in finding that federal water rights rest on a judicially created federal riparian right. Nor did the Court pay heed to the almost unbroken line of statutes by which Congress has deferred to state laws respecting water rights. ${ }^{27}$

Perhaps the most basic criticism is that the Court ignored a century of experience with western water rights which has demonstrated that the riparian right is ill-suited to a region where water is the limiting factor in land development. Had nineteenth century judges been gifted with the wisdom of hindsight, the California doctrine would have died at birth. The choice is between the logic of the California Supreme Court in Lux v. Hag$\operatorname{gin}^{28}$ and the common sense of Mr. Justice Holmes, speaking for the Su-

"Senator KucBec. So that in your opinion this Congress is powerless to require Federal properties hereafter acquired to be subject to the laws of States with respect to water.

"Mr. RANKIN. I think that is true. ..." Hearings, supra note 4, at 266-67.

27 Act of July 26, 1866, REv. STAT. $\$ 2339$ (1875), 30 U.S.C. \& 51 (1952); Act of July 9, 1870 , REv. STAT. $\$ \$ 2339,2340$ (1875), 43 U.S.C. $\$ 661$ (1952); Desert Land Act of March 3, 1877, 19 STAT. 377, 43 U.S.C. \& 321 (1952); Section 18 of the Act of March 3, 1891, 26 STAT. 1101, 43 U.S.C. $\$ 946$ (1952); Act of February 26, 1897, 29 STAT. 599,43 U.S.C. $\$ 664$ (1952); Section I of the Act of June 4, 1897, 30 StaT. 36, 16 U.S.C. $\$ 481$ (1952); Section 8 of the Reciamation Act of June 17, 1902, 32 STAT. 390, 43 U.S.C. $\$ \$ 372,383$ (1952); Section 4 of the Act of February 1, 1905, 33 STAT. 628, 16 U.S.C. $\$ 524$ (1952); Section 2 of the Act of February 21, 1911, 36 STAT. 926, 43 U.S.C. \$ 524 (1952); Section 11 of the Act of December 19, 1913, 38 StaT. 242, 250; Sections 9(b), 41 STAT. 1068, 43 U.S.C. $\$ 802$ (1952), and 27 of the Federal Power Act of June 10, 1920, 41 StaT. 1077, 16 U.S.C. \$ 821 (1952); Section 18 of the Boulder Canyon Project Act of December 21, 1928, 45 StaT. 1065, 43 U.S.C. § 617q (1952); Section 14 of the Boulder Canyon Project Adjustment Act, 54 STAT. 779 (1940), 43 U.S.C. $8618 \mathrm{~m}$ (1952); Section 3 of the Taylor Grazing Act of June 28, 1934, 48 STAT. 1270, 43 U.S.C. 8 315b (1952); Water Conservation Act of 1939, 53 STaT. 1419, 16 U.S.C. $\$ 590 z-1$ (b) (2) (1952); Great Plains Water Conservation and Utilization Projects Act of October 14, 1940, 54 StaT. 1120, 16 U.S.C. \$ 590z-1(b) (2) (1952); Section 1 of the Flood Control Act of December 22, 1944, 58 Stat. 887, 33 U.S.C. \& 701-1 (1952); Reservation (c) to the Mexican Water Treaty, U.S. Treaty Ser. No. 994, 59 Star. 1219, 1265 (1945); National Parks Act of 1946, 60 STaT. 885, 16 U.S.C. $\$ 17 \mathrm{j}-2$ (g) (1952); Section 208 of the Act of July 10, 1952, 66 STAT. 560, 43 U.S.C. $\$ 666$ (1952); Subsection 3(e) of the Submerged Lands Act of May 22, 1953, 67 STAT. 30, 43 U.S.C. $\$ 1311$ (e) (Supp. IV, 1957); Subsection 3(c) of the Act of July 28, 1954, relating to the DeLuz Dam of the Santa Margarita River, 68 Stat. 577; Section 4(b) of the Act of July 23, 1955, 69 Star. 368, 30 U.S.C. $\S 612$ (b) (Supp. TV 1957); Section 4 of the Act of July 2, 1956, relating to section 9, subsections (d) and (e) of the Reclannation Act of 1939, 70 STAT. 483, 43 U.S.C. $\$ 485$ h-(4) (Supp. TV 1957); Section 7 of the Colorado River Storage Project Act, 70 Star. 109 (1956), 43 U.S.C. $\$ 620 f$ (Supp. IV 1957).

2369 Cal. 255, 4 Pac. 919, 10 Pac. 674 (1886). Although riparian rights still exist in California, the "California doctrine," as formulated in Lux v. Haggin, is no longer in force in the California courts. See, e.g., Ivanhoe Irrigation Dist. v. All Parties, $47 \mathrm{Cal} .2 \mathrm{~d} 597,306$ P.2d 824 (1957), hearing granted and further consideration of jurisdiction postponed to hearings on the merits, 26 U.S.L. WeEx 3116 (U.S. Oct. 8, 1957), (Nos. 122, 123, 124, 125); Williams v. San Francisco, 56 Cal. App. 2d 374, 133 P.2d 70 (1942), cert. denied, 319 U.S. 771 (1943). 
preme Court in Boquillas Cattle Co. v. Curtis. ${ }^{20}$ The California court read the California statute adopted in the year of the state's admission which said that "The common law of England ... shall be the rule of decision in all the courts of this State."30 That, it said, means riparian rights. Confronted by a similar territorial statute, Mr. Justice Holmes remarked, "it is far from meaning that patentees of a ranch on the San Pedro [in Arizona] are to have the same rights as owners of an estate on the Thames." 31

The appropriative right is based on use. ${ }^{32}$ The riparian right is based on ownership of the land. The riparian right is neither acquired by use nor is it lost by non-use; it neither results in certainty, nor does it encourage maximum conservation or utilization of water resources. ${ }^{33}$ As water use and shortages spread to areas in the central and eastern part of the United States, there is a growing tendency to replace riparian doctrines with appropriation principles. ${ }^{34}$

29213 U.S. 339 (1909).

30 1850 Cal. Stats. 219. The provision now appears in Car. Crv. Code $§ 22.2$.

31213 U.S. at 345.

32 The language of the Reclamation Act, 1902, § 8, 32 STAT. 390, 43 U.S.C. $\$ 372$ (1952), that "beneficial use shall be the basis, the measure, and the limit of the right," is found in many western state statutes and constitutions. Even where not exphicitly stated, it is almost universally followed as a necessary principle of conservation.

33 A federal water right might, of course, be an appropriative right, just as a state water right might be riparian. A right based on ownership of land as in the Pelton Dam case is, however, riparian. In this connection Bannister's speculation in 1915 as to why the conflict between California and Colorado doctrines remained unresolved is of interest: "That between these two theories no final choice has been made by the Supreme Court of the United States is largely due to the fact that in the main the federal government and the state, each in its own way, have supported the priority system. With the two sovereignties thus uniting to uphold the system there has not been the occasion to decide which of the two is the one whose consent is necessary and controlling." Bannister, The Question of Federal Disposition of State Waters in the Priority States, 28 Harv. L. REv. 270, 274 (1915).

Counpare the government's argument in Kansas v. Colorado, 206 U.S. 46, 74 (1907): "The evidence clearly establishes the proposition that the application of either the strict common law doctrine of riparian rights or the so-called California doctrine to the waters of streains in the arid region, state or interstate, would have the result of preventing the reclamation and cultivation of public arid lands and defeat the pohicy of the Government witb respect thereto and would obstruct the administration of the so-called Reclamation Act of June 17, 1902." The government was there opposing both the riparian argument of Kansas and the argument of Colorado that the latter had an inherent right, independent of appropriation, to the entire flow of the Arkansas River.

34 See Ellis, Some Current and Proposed Water-Rights Legislation in the Eastern States, 41 Iowa L. Rev. 237 (1956) ; State ex rel. Emery v. Knapp, 167 Kan. 546, 207 P.2d 440 (1949). For an example of recent legislation in eastern states see the Iowa Acts 195\%, c. 229. The act establishes a permit system in which priority of time is the principal criterion: "In the consideration of applications for permits, priority will be given to persons in the order applications are received. However, persons who have made diversion or withdrawal of water for a beneficial use prior to the effective date of this Act will be accorded priority according to the actual date of said diversion or withdrawal ...." Id. \$11. Reasons why appropriative rights have proved more serviceable than riparian rights are explained by Trelease, Model State Water Code for River Basin Development, 22 LAW \& Contemp. Prob. 301 (1957). 


\section{B. The Cowlitz River Case-Navigable Water}

The Pelton Dam case is principally distinguished from earlier decisions under the Federal Power Act because it applied to a nonnavigable stream. ${ }^{35}$ Had the Deschutes River been treated as navigable, the Court would have reached the same result by following First Iore Hydro-electric Cooperative v. FPC. ${ }^{30}$

In Washington Department of Game v. FPC, ${ }^{37}$ the Court of Appeals for the Ninth Circuit sustained the Federal Power Commission's authority to license a project of the City of Tacoma on the Cowlitz River, a navigable tributary of the Columbia, over the objection of the State of Washington, which, like Oregon, was solicitous of its fish. The Cowlitz case, like the Pelton Dam case, would be reversed by the Barrett Bill, although the First Iowa case would not because Iowa has the misfortune to lie entirely east of the 98 th meridian. ${ }^{38}$

35 At least the Court said the stream was nonnavigable. However, this may well have been because the Federal Power Commission staff wanted a test case on nonnavigable water and failed to raise the navigability issue. The General Counsel of the Federal Power Commission so stated to the Senate Committee in the Barrett Bill hearings. Hearings, supra note 4, at 189. A commentator on the Pelton Dam case before its decision by the Supreme Court cautiously predicted that the Court nigbt send the case back to the Federal Power Commission for determination of the navigability of the Deschutes River. Schwartz, Federalism and Anadromous Fish, 23 GEo. WASH. L. REv. 535, 542-44 (1955).

38328 U.S. 152 (1946). The First Iowa case is notable for its statutory exegesis in disposing of $\$ 9(\mathrm{~b})$ of the Federal Power Act, which provides that "each applicant for a license under this chapter shall submit to the counmission ... (b) Satisfactory evidence that the applicant has complied with the requirements of the laws of the State or States within which the proposed project is to be located with respect to bed and banks and to the appropriation, diversion, and use of water for power purposes and within respect to the right to engage in the business of developing, transmitting, and distributing power, and in any other business necessary to effect the purposes of a license under this chapter." 41 STAT. 1068 (1920), 16 U.S.C. $\S 802$ (1952). The First Iowa project was licensed even though the evidence submitted was rather conclusive in showing that the project, which would divert nearly all of the water of the navigable Cedar River to the Mississippi at a point twenty miles above its natural poimt of entry into the Mississippi, was forbidden by Iowa law.

37207 F.2d 391 (9th Cir. 1953), cert. denied, 347 U.S. 936 (1954). Following the decision by the federal court of appeals, the state Supreme Court rejected a taxpayers' challenge to the validity of $a$ bond issue to finance the project attacked by the taxpayers on the ground that the project would violate Washington statutes designed to protect fish. Tacoma v. Taxpayers of Tacoma, 43 Wash. 2d 468, 262 P.2d 214 (1953). After remand and subsequent proceedings in the trial court, the state Supreme Court affinned a decree enjoining expenditure of money on the project on the ground that Tacoma, under state law, cannot condemn property of a state fish hatchery which the power project would inundate. Tacoma v. Taxpayers of Tacoma, 49 Wash. 2d 781, 307 P.2d 567 (1957). The City of Tacoma has filed a petition for certiorari on the ground that $\$ 21$ of the Federal Power Act, 41 Stax. 1074, 16 U.S.C. $\$ 814$ (1952), confers the power of eminent domain on the Federal Power Commission's bicensee. 26 U.S.L. WeEr 3101 (U.S. Sept. 27, 1957) (No. 509).

${ }^{38} \mathrm{~A}$ uninor departure from the promise not to quibble over draftsmanship may be permissible; why not list the seventeen states to wbich the Barrett Bill is to apply rather than sending the harried lawyer to his atlas to discover what states are covered? $C f$. S. 863, 85th Cong., 1st Sess. $\$ 4$ (1957), reproduced as Appendix II. 
Only constitutionally do the cases on navigation present a different problem from that in the Pelton Dam case. The Court has several times suggested that no constitutionally protected right can attach to navigable waters. The language from the Supreme Court's Chandler-Dunbar decision is often quoted: $:^{39}$

Ownership of a private stream wholly upon the lands of an individual is conceivable; but that the running water in a great navigable stream is capable of private ownership is inconceivable.

The statement is literally true, because the corpus of the water in any kind of a running stream is incapable of being reduced to possession, and so long as it contimues flowing, is incapable of ownership. However, jurisdiction, not ownership, is the basic issue. ${ }^{40}$ When taken to mean that there can be no usufructuary water rights in a navigable stream, the statement is mischievously wrong. Rights in navigable waters have often been recognized,11 although the navigational servitude to protect rivers as public highways has been recogmized ever since John Marshall read his historic opinion in Gibbons v. Ogden..$^{42}$ Moreover, the Court has recognized in numerous decisions that absent a federal statute the states may regulate, promote, or destroy navigation. "Ownership" of navigable waters is beside the point.

The difficulty arising in the cases dealing with navigation is that both the Congress and the courts have been content to treat the word "naviga-

${ }^{39}$ United States v. Chandler-Dunbar Water Power Co., 229 U.S. 53, 69 (1913). The language was quoted with approval in United States v. Twin City Power Co., 350 U.S. 222, 226 (1956), and paraphrased in United States v. Appalachian Elec. Power Co., 311 U.S. 377,424 (1940).

40 Confusion arises from talk about "ownership" of water in running streams, both in decisions and statutes. Water is not susceptible to ownership, and the real issue is authority to regulate. For cases involving "navigation" of highways, see Castle v. Hayes Freight Lines, Inc., 348 U.S. 61 (1954), and Colorado v. Toll, 268 U.S. 228 (1925). Both involved resolution of conflict between federal and state interests. In neither decision did the Court find it necessary to talk about who owns the highways. Bannister, The Question of Federal Disposition of Slate Waters in the Priority States, 28 HaRv. L. Rev. 270 (1915), ascribes the California doctrine to confusion between jurisdiction and ownership. Ivanhoe Irrigation Dist. v. All Parties, 47 Cal. 2d 597, 306 P.2d 824 (1957), hearing granted, 26 U.S.L. WeEK 3116 (U.S. Oct. 8, 1957) (Nos. 122, 123, 124, 125), discussed by Professor Trelease elsewhere in this issue, is an example of what happens when courts become obsessed with abstract questions like "Who owns the water?" without making the distinction between jurisdiction and proprietary ownership, corpus and usufructuary rights.

41 E.g., FPC v. Niagara Mohawk Power Corp., 347 U.S. 239 (1954); United States v. Gerlach Live Stock Co., 339 U.S. 725 (1950); Green Bay \& Miss. Canal Co. v. Patten Paper Co., 172 U.S. 58 (1898): In Monongahela Nav. Co. v. United States, 148 U.S. 312 (1893), the Court held that Congress can create rights in the proprietors of navigation structures which cannot be constitutionally taken without compensation for the franchise. Such a power in Congress strengthens, rather than weakens, the dominant servitude, since it makes possible another means of utilizing the resource.

4222 U.S. (9 Wheat.) 1 (1824).

43 E.g., Gilman v. Philadelphia, 70 U.S. (3 Wall.) 713 (1865). 
tion" as an open sesame to constitutionality. So long as Congress uses the word in a statute and the case relates to something moist, the Court takes at face value the declaration that the legislation is in furtherance of navigation. ${ }^{44}$ Moreover, the test of what constitutes a navigable stream has been stretched to embrace most of the waters in the United States. ${ }^{45}$ It has been suggested that the contemporary test may be whether a stream is navigable enough to float a Supreme Court opinion, a highly esoteric inquiry at best.

The fictitious navigable purpose was a useful judicial device at a time when Hammer v. Dagenhart, ${ }^{46}$ was prevailing constitutional doctrine, and Congress' powers under the commerce clause were all but nonexistent except where the "navigation" precedents could be invoked. Prior to United States v. Butler, ${ }^{47}$ in 1936 , it will be remembered, the Court had not discovered the general welfare clause as a source of congressional power. ${ }^{48}$

The dogma that the Court will not look behind the congressional declaration of a navigational purpose is capable of undermining many constitutional limitations. We can be confident that if Congress enacted a statute closing newspapers, prefaced by a declaration that the act was necessary to preserve freedom of speech, the Court would strike the statute down. But this is because the Court, in our generation, has been sensitive to rights under the First Amendment. Fictions are an undesirable device in constitutional interpretation, because there is no basis except the Court's own predilections to decide when a fiction is applicable.

Today, however, the Court has frankly recognized that "commerce" on navigable rivers does not necessarily mean "navigation" any more than does "commerce" on dry land. In the New River case, the Court said:49

\footnotetext{
44 See, e.g., United States v. Twin City Power Co., 350 U.S. 222 (1956); Arizona v. California, 283 U.S. 423 (1931).

45 United States v. Appalachian Power Co., 311 U.S. 377 (1940) (New River case), states the present test of navigability. A stream is legally navigable which is navigable in fact or can reasonably be made so. "Reasonably," the facts of the case make clear, is a word of art, not used in any realistic sense. Moreover, the purpose determines the scope of the definition: "Although navigability to fix ownership of the river bed or riparian rights is determined . . as of the formation of the Union in the original states or the admission to statehood of those formed later, navigability, for the purpose of the regulation of commerce, may later arise." Id. at 408.

Federal power over navigation also extends to nonnavigable headwaters of navigable streams. Oklahoma ex rel. Phillips v. Guy F. Atkinson Co., 313 U.S. 508 (1941) (Denison Dam case) ; United States v. Rio Grande Dam \& Irrigation Co., 174 U.S. 690 (1899).

46247 U.S. 251 (1918) (Child labor law held unconstitutional).

47297 U.S. 1 (1936).

48 A hint of that discovery, however, is contained in United States v. Gettyshurg Ry. Co., 160 U.S. 668 (1896), which upheld federal power to condemn a portion of the Gettysburg battlefield for public purposes.

Cf. United States v. Gerlach Live Stock Co., 339 U.S. 725 (1950), where the Court found constitutional justification for federal construction of the Central Valley Project of Cahiornia in the general welfare clause.
}

49 United States v. Appalachian Power Co., 311 U.S. 377, 426 (1940). 
By navigation respondent means no more than operation of boats and improvement of the waterway itself. In truth the authority of the United States is the regulation of commerce on its waters. Navigability, in the sense just stated, is but a part of this whole.

What then can be the justification for the difficult judicial inquiry which the Court in that case pursued as to whether boats once plied interstate waters, or might conceivably do so again, if the congressional purpose has nothing to do with boats? ${ }^{50}$ The navigation fiction is at best a waste of legal talent, making decisions hinge on essentially irrelevant and obscure facts. At its worst, it is positively pernicious, when a fictitious declaration of navigable purpose is used as a reason for permitting the United States to take property without coinpensation, as it succeeded in doing in United States v. Twin City Power Co., ${ }^{51}$ decided last year. Navigation is commerce. Railroading is commerce. Agriculture either is commerce or affects commerce to the extent necessary to subject it to federal regulation. ${ }^{52}$ All these activities Congress can and has regulated. Yet in all but the "navigation" aspect of commerce, Congress cannot take property without conpensation. ${ }^{53}$

50 An example of a purposeless inquiry is Economy Light \& Power Co. v. United States, 256 U.S. 113 (1921). The Court affirmed a decree in favor of the United States enjoining construction of a dam in a "navigable" river without securing approval required by $\S 9$ of the Rivers and Harbors Act of 1899, 30 STaT. 1151, now 33 U.S.C. $\$ 401$ (1952). The river had not been used for navigation since the first quarter of the nineteenth century. The Court said that drainage of a swamp and clearing away of forests affecting rainfall and the distribution of runoff were among the factors which had destroyed navigability in fact, but not in law. 256 U.S. at 118. One may ask whether courts will still be taking evidence in the twenty-fifth century to determine whether a stream in the nineteenth century was navigable in fact, or could reasonably be - or perhaps have been-made navigable.

51350 U.S. 222 (1956) (5-4 decision). The Court held that no compensation is required with respect to that part of the value of condemned upland which inhered as a result of the land's availability as a power site adjacent to navigable water.

Concerning the Twin City and Chandler-Dunbar decisions a writer in the Harvard Law Review has commented: "[T] tude in the flow of the stream so that the servitude includes the value which the presence of the How imparts to adjoining property. This result was reached without discussion of the consequences which logically follow. The Government's argument, for example, might require an irrigated farm to be valued as desert land. By permitting the Government to base its argument on the hypothesis that it would exercise arbitrary power, the Court ignored the improbability of such arbitrary action, and the sanctions, both judicial and political, which may follow upon capricious destruction of property value." Note, The Supreme Court, 1955 Term, 70 HaRv. L. REv. 83, 134 (1956).

Compare United States v. Gerlach Live Stock Co., 339 U.S. 725, 737 (1950): "[W]e need not ponder whether, by virtue of a highly fictional navigation purpose, the Government could destroy the flow of a navigable stream and carry away its waters for sale to private interests without compensation to those deprived of them. We have never held that or anything like it, and we need not here pass on any question of constitutional power ...."

52 Wickard v. Filburn, 317 U.S. 111 (1942).

53 See, e.g., United States v. Causby, 328 U.S. 256 (1946). 
These matters involving constitutional powers are beyond the reach of the Barrett Bill to affect. They are considered here because they have had an important bearing on the conflicts which have given rise to the Barrett Bill. It is well to consider them, moreover, because the constitutional doctrines of the Supreme Court are not fixed or static, but are shaped and influenced over the years by an enlightened bar. The immediate effect of the Barrett Bill would be to reverse decisions like the Cowlitz River case, and while it would not surround water rights with any constitutional safeguards, it would permit the states the last word on whether unappropriated water, navigable or not, is to be used for irrigation and other consumptive use, for salmon spawning, or for federally chosen purposes. Ultimately, we can hope that the majority view of the Twin City case will give way to the more rational view of the Court's minority. ${ }^{54}$ The Court may yet take the view, as phrased by Mr. Justice Brandeis in Port of Seattle v. Oregon \& Wash.R.R., that: ${ }^{55}$

The right of the United States in the navigable waters within the several states is limited to the control thereof for purposes of navigation. Subject to that right Washington became, upon its organization as a state, the owner of the navigable waters within its boundaries and of the land under the same.

Fortunately, the Court has not yet gone so far as to hold that the magic word "navigation" can be used to take one person's water right and give it to another without compensation. The consequences, were the Court to take that position, can best be judged by reference to contentions currently being made in Arizona v. California, No. 10 Original, now being tried by a Special Master under order of reference from the Supreme Court. ${ }^{56}$ Five states -Arizona, California, Nevada, New Mexico, and Utah-and the United States are seeking a determination of their right to use the waters of the lower basin of the Colorado River system, as defined by the Colorado River Compact. ${ }^{57}$ Arizona has made a contention, concurred in by counsel for the United States, that no appropriation of navigable waters is possible without a permit from the Secretary of War under the Rivers and Harbors Act of 1899.58

54350 U.S. at 229.

55255 U.S. 56, 63 (1921). The passage in text was quoted, in part, by Judge John J. Parker In United States v. Twin City Power Co., 215 F.2d 592, 597 (4th Cir. 1954), one of the two decisions reversed by the Supreme Court in Twin City.

50344 U.S. 919 (1953) (motion for leave to file bill of complaint granted); 347 U.S. 985 (1954) (order of reference to special master); 350 U.S. 812 (1955) (order appointing successor to deceased special master).

${ }^{57}$ Art. II(g). Wilbur and Ely, Hoover Dan Documents, H.R. Doc. No. 717, 80th Cong., 2d Sess., p. A18 (1948).

E8 30 STAT. 1151, 33 U.S.C. $\$ \$ 401,403,406$ (1952).

Another Arizona contention is that appropriative rights are "merged," i.e., their priorities are destroyed by water delivery contracts executed under authority of the Boulder Canyon 
The contention is based on United States v. Rio Grande Dam \& Irrigation Co. ${ }^{59}$ decided by the Supreme Court in 1899 under an earlier version of the 1899 Act, $^{60}$ when the government sued to enjoin a proposed dam at Elephant Butte in New Mexico on the Rio Grande. The Court took judicial notice that the Rio Grande in New Mexico is nonnavigable, but directed a trial on the issue whether the dam would interfere with navigability in the lower reaches of the stream. The case was finally disposed of on the ground that the irrigation company had not protected its right of way, ${ }^{61}$ and from that day to this, apparently no appropriation has been invalidated because it attaches to navigable water.

If the contention of Arizona prevails, most appropriative rights throughout the western states will be invalidated.$^{62}$ Under current decisions, most streams in the United States are navigable, or they feed streams which are navigable, like the New Mexico reaches of the Rio Grande. Even the water rights of projects of the United States Bureau of Reclamation will be invalidated. ${ }^{63}$ Only a few western streams can clearly be said to be nonnavigable,

Project Act, 45 STAT. 1057 (1928), 43 U.S.C. $\$ \$ 617-17$ t (1952), for water stored by Hoover Dam. Extended argument relating to this issue was heard by the special master on Arizona's objections to evidence of California appropriative rights. The California evidence was admitted, but ruling on the substantive issue has been reserved.

59174 U.S. 690 (1899).

6026 STAr. 454 (1890).

61 Rio Grande Dam and Irrigation Co. v. United States, 215 U.S. 266 (1909). See also United States v. Rio Grande Dam and Irrigation Co., 184 U.S. 416 (1902) (another proceeding in the case).

The Rio Grande case was one phase of the so-called "embargo" on development of the Rio Grande imposed by order of the Secretary of the Interior directed to the Commissioner of the General Land Office on December 5, 1896. It was implemented principally by refusal to grant rights of way through public lands for purposes of irrigation. Documents are assembled in the Secretary of the Interior's report to Congress made in 1911, printed as H.R. Doc. No. 39, 62nd Cong., 1st Sess. (1911). It appears from this report that the Rio Grande suit was instituted on the initiative of the State Departmeut as a result of claims of interference with vested rights presented by Mexico. Id. at 13.

62 Apparently only in rare instances have appropriators had occasion to apply to the Secretary of War for perınits under the Rivers and Harbors Act, 30 STAT. 1151 (1899), 33 U.S.C. $\S \S 401,403,406$ (1952). Some of the California appropriators whose rights are being litigated in Arizona v. California did secure such permits at an early datc. Arizona counsel, on motion to compel production of any permits to Arizona appropriators, some of whose rights also go back decades, disavowed knowledge of the existence of such permits. Daily Transcript 9922, July 9, 1957.

63 See opimion of Mr. Justice Douglas in United States v. Gerlach Live Stock Co., 339 U.S. $725,759-61$ (1950). The issue was whether the United States inust compensate the owners of riparian rights on the navigable San Joaquin River which the United States had taken for Califormia's Central Valley Project.

"Whatever doubts there may be are for me dispelled by the administrative practice under the Act, as summarized by the Commissioner of Reclamation in a memorandum dated April 19, 1950. Reports from the seven regional counsel and a review of the files in the Bureau of Reclamation forned the basis for the memorandum.

"The Commissioner concluded that it has been the almost invariable practice of the Burcau 
and some of these, until an adjudication, can constitute only the basis of a risky prediction.

"Navigation" has not yet been invoked to destroy existing appropriative rights, but the fear that it may is a potent force in producing support for the Barrett Bill.

\section{Underground Water-the Hawthorne Case}

The third case which has convinced many westerners that "there ought to be a law" relates to waters underlying the Hawthorne Naval Ammunition Depot at Hawthorne, Nevada. Titled Nevada ex rel. Shamberger $v$. United States, the suit has been brought by Nevada for declaratory relief in the Fifth Judicial District of that state, and removed to the Federal District Court where it is now pending. ${ }^{64}$

When the Pelton Dam case was decided, the Naval Ammunition Depot at Hawthorne had pending six permits to appropriate ground water under the law of Nevada from six wells on the depot. All that reinained for the government to do was to file proofs of beneficial use and to pay a filing fee of $\$ 6-\$ 1$ per permit. Less than three weeks after the Pelton Dam case was decided, the commanding officer advised the State Engineer that he was withdrawing the applications on instructions from the Commandant of the Twelfth Naval District, an action based on the Supreme Court's decision. The wells were located on public lands withdrawn from entry about 1933 and reserved for use of the Navy Department by executive order.

The government insists that it is upholding a principle. ${ }^{65}$ No contest or dispute over the applications existed. The State Engineer might even have been persuaded to sponsor a charitable subscription to raise the $\$ 6.00$.

to file notices of appropriations under state law without regard to whether the stream involved was navigable or nonnavigable. Such filings were made pursuant to state law on water rights riparian to at least 13 navigable or probably navigable rivers. . . " United States v. Arizona, 295 U.S. 194 (1935), holds that agencies of the United States Government are, like other parties, subject to the prohibitions of the Rivers and Harbors Act.

84 Consent to suit against the United States is found in 66 STAT. 560 (1952), 43 U.S.C. $\S 666$ (1952).

65 The Department of Justice, even where there is no federal-state friction, apparently insists on the government's maintaining its position of noncompliance with ground water laws. In Arizona v. Califormia, the then Arizona State Land Commissioner, Mr. Roger Ernst, testified under California cross-examination that the Arizona ground water law administered by him is being fully enforced on all federal reservations, including Indian reservations (Daily Transcript 3629 , July 25,1956 ). Government counsel in turn developed through cross-examination of the same witness, that an Indian has in fact drilled a well in defiance of the law (id. at 364849), and that nothing thereafter happened by way of enforceinent. Mr. Ernst agreed with counsel when asked, "They [the government] have on each apphication made the observation that they are doing it in a cooperative spirit but reserving the right to contend that they are not obligated to do so?"

Answer: "Usual procedure, yes, sir." Id. at 3650. 
Must or should the United States comply with Nevada law relating to underground water?

Ground water laws are rapidly becoming a necessity throughout the west. They are based on a recognition that an underground basin is a common source of supply to many overlying water users, and that its safe yield is measurable in finite quantities. Disaster waits for those who must learn this lesson by experience.

The Nevada ground water law is for the benefit of all users of ground water, the Navy Department included. If a federal installation can exhaust an underground source available to other users, so likewise can other users, unless restrained, exhaust the source available to the installation.

This is not a conflict between state law and federal law. If the United States does not comply with the ground water law of Nevada, it is without the law, since it has no law of its own to substitute. There is, as yet, no navigation fiction applicable to subterranean waters, with the solitary exception of the River Styx. Even disregarding constitutional limitations, one can scarcely conceive of a federal ground water code applicable to an entire region of the United States. Yet short of that eventuality, if the government is upheld, it means that there can be no effective ground water control in any area where there are large federal installations on withdrawn public lands. ${ }^{68}$

The Hawthorne case presents, in sharpest relief, a problem common to all three of the cases here discussed. Justice Department representatives in opposing the Barrett Bill have said that it will subject federal functions to diverse state laws. ${ }^{67}$ They insist that federal rights attach to lands which the United States has acquired by purchase or condemnation. ${ }^{68}$ They insist

${ }^{66}$ A special statute, 41 Stat. 293 (1919), 43 U.S.C. $\$ 351$ (1952), authorizes the Secretary of the Interior to issue permits which give an exclusive right to drill or explore for underground water beneath the surface of unreserved, unappropriated, nonmineral, nontimbered public lands in Nevada not known to be susceptible to irrigation at reasonable cost. The statute does not relate to the water right which the permittee may secure under Nevada law.

${ }^{67}$ See, e.g., the testimony of J. Lee Rankin, Hearings, supra note 4, at 243-85; Hearings, sapra note 3 , at $10-70$.

B8 Testimony of J. Lee Rankin, note 26 supra. Mr. Rankin, lowever, seems to be at odds with the Navy Department lawyers as to water rights with respect to acquired government land. The commanding officer of the Hawthorne Depot wrote State Engineer Shamberger on December 8,1955 , making this distinction as to pending surface water application for permits to appropriate:

"Enclosed are the application and map for permit to appropriate the waters (complete flow) from Squaw Creek. All privately owned land within the confines of the depot which Squaw Creek crosses has been acquired by the Government, together with all privately owned water rights. Payment in the amount of $\$ 25$ covering the required filing fee for the above application will be made through regular Navy cliannels.

"Since all water from House Creek flow entirely over land withdrawn from the public domain and reserved for the use of the United States naval ammunition depot, an application to appropriate the waters of House Creek will not be filed with the State engineer, State of Nevada." Hearings, supra note 4, at 79. 
on unlimited ground water rights in regions where states have found regulation of ground water an absolute necessity. They present this position as a conflict between federal and state law in which state law, when inconsistent, must yield.

In fact, however, there is no federal law of riparian rights in a reahistic sense, just as there is no federal ground water law. Each state in the west has a large and reasonably well integrated body of law on the subject of water rights; the federal government does not. In most states, an attorney should be able to give a reasonably clear and definite answer to a client with a water right problem. If the conpeting user is the United States, such an answer is likely to be difficult. If the conpeting user is the United States withdrawing water from a common underground basin, the answer-at least until decision im the Hawthorne case-is impossible.

Water law is real property law. This is not merely a law book publisher's vagary of classification, but rests on the fact that water and soil, and rights to their use, are inextricably related. In real property law, certainty is the highest virtue: it is better that the law be certain than that it be enlightened. That statement nray shock laymen, but it is readily understood by lawyers. The federal government could not alter a state's rule against perpetuities without creating chaos in land titles. Why should it modify the law of water rights?

Justice Department attorneys may have overlooked the fact that rights of the United States, if they rest on undefined federal principles, are no less insecure than state-created rights, save as the governnient can take refuge in sovereign immunity. Suppose the government wins the Hawthorne dispute. Can the commanding officer at Hawthorne relax in the assurance that his six wells will continue to tap an accessible water supply, ready for a national enrergency? Can his Commandant's counsel tell him what rule of law will apply if he is forced to hitigate in defense of the water supply available to those wells ${ }^{69}$

60 Physically federal and non-federal lands overlying a common ground water basin are like federal and non-federal lands overlying a common pool of oil or gas. Both federal statutes and regulations recognize the latter problem in realistic efforts to deal witl it. When oil or gas is being drained from United States lands by wells on adjacent lands, the Secretary of the Interior may negotiate compensatory royalty agreements. 60 STAT. 952 (1946), as amended, 30 U.S.C. $\$ 226$ (Supp. IV 1957). Federal oil and gas lessees may unite in unit operation with other persons whenever determined by the Secretary necessary or desirable in the public interest. A plan of unit operation may vest authority in the Secretary or in such "person, committee, or State or Federal officer or agency as may be designated in the plan, to alter or modify from time to time the rate of prospecting and development and the quantity and rate of production under such plan." 60 STAT. 952-53 (1946), as amended, 30 U.S.C. \$226e (Supp. IV 1957). The statute with respect to these provisions expressly provides that nothing shall be construed "to affect the rights of the States or other local authority to exercise any rights which they may have ... " 41 STAT. 450 (1920), 30 U.S.C. \$ 189 (1952).

United States Department of the Interior, Bureau of Land Management Form No. 4-1158, 
Or consider the power company now building its plant at the Pelton site in Oregon. Is the riparian right, of which it has become the beneficiary through the operation of federal law, subject to the doctrine of correlative rights, so that it must yield to the reasonable needs of other riparians whose needs may later develop? Or has it the security of an appropriative right, suggested by the terms of the license?

Activities of the federal government are many times greater in magnitude than they were thirty years ago. The prospect that federal activity and federal ownership of real estate will increase is at least as good as the prospect that they will decline. If rights of the federal government are to be governed by nonexistent federal law, federal-state friction will be an increasingly serious problem. Water law, to the extent it is federal law, is likely to be neither just nor certain.

\section{II \\ THE BARRETT BIIL AN ANSWER?}

Two of the three cases discussed above arose under the Federal Power Act. The purposes of the Barrett Bill with respect to that Act could be achieved by a rather simple amendment to that statute. Some language to say, "and we really mean it," added to sections 9 (b) and 27 would accomphish that purpose. ${ }^{70}$ The third case is the Hawthorne case in Nevada, not yet decided. That problem could be disposed of, if the courts do not do so earlier, by a sinple statute providing that in the use of underground water on any property belonging to the United States, the United States shall comply with any state law which is not discriminatory against the federal government, preserving to the United States its power of eminent domain.

Absent statutes authorizing federal activity, powers of the United States with respect to water, if existent, are negligible. Why not, therefore, deal with the problems as they arise under various federal statutes? The success of narrow and specific statutes is likely to be better in the courts

Offer to Lease and Lease for Oil and Gas $\$ 4$ (6th ed. 1957) provides: "It is agreed that the rato of prospecting and developing and the quantity and rate of production from the lands covered by this lease shall be subject to control in the public interest by the Secretary of the Interior, and in the exercise of his judgment the Secretary may take into consideration, among other things, Federal laws, State laws, and regulations issued thereunder, or lawful agreements among operators regulating either drilling or production, or both. After unitization, the Secretary of the Interior, or any person, committee, or State or Federal officer or agency so authorized in tho unit plan, may alter or modify from time to time, the rate of prospecting and developunent and the quantity and rate of production from the lands covered by this lease."

See also 30 C.F.R. § 226.12 (1956); 43 C.F.R. § 192.20 (1954).

70 A proposal to amend $\S 27$ of the Federal Power Act was the object of S.3250, 84th Cong., sponsored by Senators Neuberger and Morse of Oregon. For text see S. REP. No. 2587, 84th Cong., 2d Sess., to accompany S. 863, p. 47 (1956). Senator Neuberger later offered an amendment which became $\S 11$ of the current S. 863. See Appendix II. 
than that of a statute attempting to deal with all problems at once. When each problein is clearly seen in context it can be dealt with inore successfully. Practically, however, the Barrett Bill may be easier to enact, because it is easier to inuster support to right one hundred wrongs than to right one wrong.

Nevertheless, the narrow statute-by-statute approach has much to recommend it. Let us take an example. Today, under section 8 of the Federal Reclamation Act of $1902,{ }^{71}$ the case law leaves little doubt that water rights for federal reclamation projects are strictly governed by state law. ${ }^{\mathbf{2}}$ The Barrett Bill sponsors are quite happy with this situation, and provide in section 10 of the current bill that ${ }^{73}$

The provisions of this Act shall not be construed as repealing or affecting any of the provisions of section 8 of the Reclamation Act of 1902, but shall be construed as being supplementary thereto.

However, section 7 of the bill provides: ${ }^{74}$

Nothing in this Act shall be construed ... to affect, impair, diminish, or enlarge any existing water rights in Indians, Indian tribes, or persons claiming under or through them or any Federal reclamation project heretofore authorized by the United States.

The implication froin this language is strong that with respect to reclamation projects heretofore authorized, some provision of the Barrett Bill might be construed to enlarge or diminish water rights. If section 8 of the Reclamation Act is truly unaffected, and consistent with the Barrett Bill, why the distinction between new reclamation projects and those "heretofore authorized by the United States"?

No doubt both the provision preserving section 8 of the Reclamation Act and the provision with respect to presently authorized reclamation projects are inserted out of an abundance of caution. Probably, these provisions will result in neither harm to the bill's basic objectives nor confu-

71 "[N]othing in this Act shall be construed as affecting or intended to affect or to in any way interfere with the laws of any State or Territory relating to the control, appropriation, use, or distribution of water used in irrigation, or any vested right acquired thereunder, and the Secretary of the Interior, in carrying out the provisions of this Act, shall proceed in conformity with such laws, and nothing herein shall in any way affect any right of any State or of the Federal Government or of any landowner, appropriator, or user of water in, to, or from any interstate stream or the waters thereof: Provided, That the right to the use of water acquired under the provisions of this Act shall be appurtenant to the land irrigated, and beneficial use shall be the basis, the measure, and the limit of the right." 32 STaT. 390 (1902), 43 U.S.C. $\$ \S 372,383$ (1952).

72 See Nebraska v. Wyoming, 325 U.S. 589, 611-16 (1945); Ickes v. Fox, 300 U.S. 82 (1937), and (following remand) Fox v. Ickes, 137 F.2d 30, 33 (D.C. Cir. 1943), cert. denied, 320 U.S. 792 (1943).

${ }^{73}$ S. 863,85 th Cong., 1st Sess. $₹ 10$ (1957), reprinted berewith as Appendix $\Pi$.

74 Id. $\$ 7$ (Einphasis added.) 
sion; nevertheless, they provide material for a lawyer's argument that federal reclamation projects "heretofore authorized" are not intended to be controlled by appropriative rights under state law.

The statute-by-statute technique would involve an inquiry into the Reclamation Law. If there were reason for dissatisfaction, it would amend that law. If there were no reason for dissatisfaction, it would leave the law alone. It would be unnecessary to write a general and sweeping bill with numerous "nothing-herein-shall-be-construed" provisos.

\section{A. The Indian Problem}

Other objections to the Barrett Bill have been suggested by those sympathetic with its principles. One such objection is its failure to deal with the problem of Indian water rights. In section 7, already quoted, ${ }^{7 \sigma}$ there is the provision that nothing shall be construed as affecting existing water rights in Indians, Indian tribes, or persons claiming under or through them.

The law and the administration of Indian water rights is in a wholly unsatisfactory state. The leading decision is Winters v. United States, ${ }^{70}$ decided in 1908. It is a cryptic and obscure opinion, incapable of being understood, if at all, without reference to the prior opinion in the Ninth Circuit Court of Appeals. ${ }^{77}$ It has been taken as holding that when reservations were created for Indians, there was impliedly reserved by operation of the treaty or executive order the right to the use of all water reasonably neces. sary for the needs of the Indians.

The Winters case presents at least two major questions:

(1) Does the Winters implied reservation of water rights include water reasonably considered necessary at the time of creation of the reservation, or is this an indefinitely expandable mortgage which the United States holds in behalf of Indians?

(2) To what extent, if at all, does the reservation operate in favor of transferees from Indians? Or, to put it another way, is the reservation of water for Indians confined to the needs of those who become farmers and irrigators, or is it a water right which may be exploited by lease or sale to nonIndians for the financial benefit of the Indian members of a tribe, like oil discovered on Indian land?

The position of the Department of Justice on the first question has been formally stated in answer to an interrogatory to the United States in Arizona v. California, ${ }^{78}$ now before the Special Master. With reference to

75 Text at note 74 supra.

76207 U.S. 564 (1908).

77 Winters v. United States, 143 Fed. 740 (9th Cir. 1906).

78 Discussed in text at note 56 sicpra. 
Indian claims which the United States is pressing in Arizona, California, Nevada, New Mexico, and Utah, California asked: ${ }^{79}$

Does the United States claim the right, for the benefit of Indians, to initiate Indian uses at any time in the indefinite future, to the detriment of present or intervening non-Indian uses and rights?

After objection to the interrogatory was overruled, the government answered:

Yes, within the limits of the quantities of water claimed on behalf of the Indians and Indian Tribes for their ultimate usage..$^{80}$

This uncertainty is not good for Indians; it is not good for non-Indians. It gives neither Indians nor non-Indians a clear title, and leaves as the source of Indian water rights a conglomerate mass of unconstrued treaties, agreements, and executive orders. Indians occupy thousands of square miles in the western states. ${ }^{81}$ Unless Indian rights can be established and fixed with reasonable certainty, rather than resting on claims of whatever "reasonable needs" may develop, the pressures created may result ultimately in smaller Indian rights than if Indian claims were established like those of other users in the states in which the Indians live. The time for an orderly procedure which will end the Indian water right chaos has long passed. The initiative, however, must remain with the Bureau of Indian Affairs and the Congress. Legal guideposts leave so inuch to be desired that the outconie of Indian water rights litigation in the courts is almost as conjectural as trial by combat.

An example will serve to illustrate. An Indian case now in progress is the Ahtanum case in the State of Washington. ${ }^{82}$ The District Judge's sympathies were with the non-Indian irrigators: ${ }^{83}$

It is not just to encourage them to spend more than a generation building communities on the basis of this water, and then arbitrarily confiscate it on

79 California Interrogatory C-11, Feb. 28, 1956.

80 United States' Answer to California Interrogatory C-11, June 12, 1956. "Quantities of water claimed" by the United States in Arizona v. California are very large-over 1,500,000 acre-feet per annun of diversions, and over 750,000 acre-feet per annum of consumptive use for Indians in the five states. United States' Answer to California Interrogatory 0-3, dated Aug. 2,1957 . This claim is a substantial reduction, however, from the $1,747,250$ acre-feet of "ultimate" diversions claimed for Indians in Arizona and California alone when the Umited States Petition for Intervention was filed in 1953. At that time the government alleged that 747,170 acre-feet was the "present" diversion for Arizona and California Indian reservations, a little over $40 \%$ of the ultimate claim.

81 Over 1,000,000 acres have been added to Indian tribal holdings in the last three years. Department of the Interior, Bureau of Indian Affairs Press Release, May 7, 1957.

82 United States v. Ahtanum Irrigation Dist., 124 F. Supp. 818 (E.D. Wash. 1954), judgment of dismissal rev'd, 236 F.2d 321 (9th Cir. 1956), cert. denied, 352 U.S. 988 (1957). The case is now back in the federal district court for trial.

83124 F. Supp. at 837 . Opinion by Judge Fee, simce elevated to the Court of Appeals for the Ninth Circuit. 
the basis of a claimed reservation never expressed in words for almost a century.

Again, after referring to a 1908 agreement between the tribe and the Indian Service and to a 1925 state court adjudication in which the United States might have participated, but did not, he said: ${ }^{84}$

[These events] show that there was no intention to make the claim here until a false construction of the Winters case awakened the power-grasping instincts of the bureaucrats.

The Court of Appeals' opinion reversing the District Court also shot sparks, but in a quite different direction: ${ }^{85}$

The numerous sanctimonious expressions to be found in the acts of Congress, the statements of public officials, and the opinions of courts respecting "the generous and protective spirit which the United States properly feels toward its Indian wards", ... and the " "high standards for fair dealing' required of the United States in controlling Indian affairs", . . . are but demonstrations of a gross national hypocrisy.

... The Secretary's [of the Interior] mistakes, his poor judgment, his overlooking or ignoring of the true measure of the Indians' rights, his lack of bargaining skill or determination may add up to an abuse of his power, but do not negative it, or make his act ultra vires.

These are able judges. Such bitter differences of opinion from identical facts can only result because the law does not provide adequate materials for decision.

The second problem, the status of transferees holding Indian water rights under long-term lease or sale is also serious, and is closely related.

Water uses by Indians themselves are unlikely to be large. ${ }^{80}$ If, however, Indian water rights are to be exploited by non-Indians for cash considerations used to finance other Indian programs, an Indian problem of new proportions arises. For example, on August 14 of this year, the government announced the execution of a twenty-five year lease of about 67,000 acres on the Colorado River Indian Reservation in Arizona to a single commercial corporation, the land to be developed and used for a cash

84 Id. at 841 .

85236 F.2d at 338 (9th Cir. 1956). The court upheld the validity of the agreement it thus denounced.

86 For example, in Arizona v. California the United States claims 39,705 acre-fect of diversions per annum for use on 7,743 acres of the Yuma Reservation in California. United States' Answer to Interrogatory 0-3, dated August 2, 1957. The Project Manager of the Bureau of Reclamation's Yuma Project which serves water to this reservation has testified that there are presently nine Indian operators, and 42 non-Indian lessee operators. About 450 acres, between 10 and $15 \%$ of the lands presently irrigated, are operated by Indians. Daily Transcript 8821, July 1, 1957. 
rental to the United States and restored to Indian control after 25 years. ${ }^{87}$ This is more than twice as much acreage as that currently cultivated on that reservation. Indeed it is approximately fourteen per cent of the 540,000 irrigated acres of irrigated Indian land in the whole United States reported in $1952 .^{88}$ In the liglit of the congressional policy to terminate wardship and special status for Indians as soon as possible, the chances of a return of this land to Indians are remote. ${ }^{89}$

Moreover, even if financially profitable, the Colorado River lease will benefit only an estimated 1,300 Indians associated with that reservation. The Navahos, for whom population estimates range from sixty to over eighty thousand, will be in as bad shape as ever. ${ }^{80}$

87 Department of the Interior, Bureau of Indian Affairs Press Release, August 14, 1957. Proceeds of the lease are to be deposited in the U.S. Treasury to the credit of the Indians determined to be beneficial owners. A controversy over ownership is before the Indian Claims Commission. The lease was apparently signed in some haste on the last day before the Secretary of the Interior's authority to do so under 69 STAT. 725 (1955) expired. The status of the lease is currently in doubt because of the lessee's failure to post the prescribed $\$ 5,000,000$ performance bond within 30 days. The lessee's request for a 90-day extension has been referred to the Department of Justice. Department of the Interior, Bureau of Indian Affairs Press Release, September 26, 1957.

88 H.R. REP. No. 2503, 82 d Cong., 2d Sess. 75 (1952).

89 See, e.g., H.R. Conc. REs. 108, 83d Cong., 1st Sess., 67 Stat. B132 (1953), which declares that "it is the policy of Congress, as rapidly as possible, to make the Indians within the territorial limits of the Urited States subject to the same laws and entitled to the same privileges and responsibilities as are applicable to other citizens of the United States, to end their status as wards of the United States, and to grant them all of the rights and prerogatives pertaining to American citizenship ...."

Definition of Indian water rights at or prior to termination of Indian guardianship and distribution of assets to Indians with alienable title is a necessity. See 68 STAT. 722 (1954), 25 U.S.C. $\S 564 \mathrm{~m}$ (Supp. IV 1957) (terminating guardianship of the Klamath tribe). This act provides that Oregon laws with respect to abandonment of water rights by nonuse shall not apply to the tribe and its members until fifteen years after the proclamation making termination effective. Nothing is said about non-Indian transferees.

H.R. 2824, 85th Cong., 1st Sess. $\$ 4$ (1957), as reported by the House Interior and Insular Affairs Committee, relating to termination of certain reservations and rancherias in California, would make California law mapplicable to water riglits to the extent not now applicable, and "while the water right is in Indian ownership." During the fifteen year period the United States Attorney General would represent Indians in legal proceedings. H.R. REP. No. 1129, 85th Cong, 1st Sess. (1957).

H.R. 9512, 85th Cong., 1st Sess., introduced on August 28,1957 , by Representative Utt. of California, provides for termmation of all Indian guardianship in California and distribution of assets. This bill would set up a commission to undertake comprehensive fact finding with respect to "ascertainment and determination" of all Indian water rights in the state. Findings of fact would be "prima facie evidence of the claim of water right" but would not constitute an adjudication. Id. § 5. The Utt Bill does not answer the sixty-four dollar question: What facts are relevant to prove an Indian water right? The only substantive guide is $\S 9(j)$ suspending operation of California law with respect to loss of a water right by nonuse for five years after termination. Representative Sisk of California introduced an identical bill, H.R. 9530, 85th Cong., 1st Sess., on August 29, 1957.

90 The 1950 Census reports 342,226 Indians in the United States, 181,248 in the states of Montana, Wyoming, Colorado, New Mexico, Idaho, Utah, Arizona, Nevada, Washington, Oregon, and Califorma. There were 60,424 in these states classified as "rural farm" Indians. 
No reasonable person can deny that the United States has good reason for a troubled conscience with respect to its Indians. If Indians need water to maintain their farms they should have it. If they need money for education, health, or welfare, or to assist their assimilation into the non-Indian population, they should have it. There can be no excuse, however, to barter a priceless natural resource-water-simply because that appears to be the most expedient way to raise money.

Fiscal and social aspects of the Indian problem is beyond the scope of the Barrett Bill, but the legal status of transferees of Indian water rights is not. United States v. Povers ${ }^{91}$ has sometimes been cited for the proposition that non-Indian transferees succeed to Indian rights. Actually, the case did not so hold, since the plaintiff was the United States suing in behalf of its Indian wards, and the defendants were non-Indian claimants under Indian allottees, residing on the Indian reservation. The legal rights of the transferee of an Indian water right appear to be, like many other Indian problems, murky.

The Barrett Bill in its present form might well be cited to support rights of non-Indian transferees. Reference in section 7 to "persons claiming under or through" Indian tribes at least adds color to the view that such rights are transferable. If the intent is to leave the Indian problem alone, it would be advisable to omit reference to transferees, and let the courts wrestle unaided with the problem when the "Winters doctrine" comes up for review.

This suggests another danger, however, that cannot be so easily avoided. Legislation announcing itself as "The Western Water Rights Settlement Act of 1957 " is very likely, unless it deals with the Indian problem, to be taken as an indication that Congress left Indian water rights alone because it is well satisfied with the Winters case and the generalizations that case is sometimes used to support. This is another reason to prefer the statuteby-statute treatment, rather than the technique of the Barrett Bill, if the Barrett Bill is to leave one of the sorest spots in current water law untreated.

\section{B. The Sovereign Immunity Problem}

Another niadequacy in the Barrett Bill is more serious than its failure to deal with Indians. No right is stronger than the ability of its owner to enforce it. Many water rights have been defended - as well as assaulted -by self help. But there are inhibitions in our society against indiscriminate use of shooting irons; the courts are the primary vindicators of legal rights.

81305 U.S. 527 (1939). 
Federal interests make the United States an indispensable party to many lawsuits over water. The United States cannot be sued without consent granted by Congress. Arizona v. California, ${ }^{92}$ the third of Arizona's four suits against California on the Colorado River, is a leading case. Its principles apply to a suit between private parties as well as to suits against the United States. Under Ickes v. Fox, ${ }^{93}$ the Secretary of the Interior can be sued without joining the United States, where he has illegally threatened interference with rights of water users under a federal reclamation project. While Ickes v. Fox is still good law on its substantive interpretation of section 8 of the Reclamation Act, ${ }^{94}$ its authority on the availability of a suit where consent of the United States has not been given to be joined has been weakened by Larson v. Domestic and Foreign Commerce Corp. ${ }^{95}$ Nere Mexico v. Backer, ${ }^{96}$ in the Tenth Circuit, held that Ickes v. Fox on indispensability has been in fact overruled.

The Barrett Bill, after it was first amended to become the Water Rights Settlement Act of 1956, contained a section 7 designed to correct this condition by giving consent of the United States to suit. A section 8 deprived this provision of a part of its virtue in making it inapplicable to suits over interstate streams in the original jurisdiction of the United States. ${ }^{97}$

Regrettably, the present Barrett Bill has omitted any consent-to-suit feature. To some extent, this deficiency is supplied by section 208 of the Act of July 10, $1952^{98}$-often called the McCarran Act-which provides some of the language of the consent-to-suit provision deleted from the present version of the Barrett Bill. However, the 1952 law also contains an exception eliminating consent to becone a party to suits in the original jurisdiction of the Supreme Court, ${ }^{89}$ and it is not as broad as it should be even with respect to suits in other courts. ${ }^{100}$

92298 U.S. 558 (1936).

93300 U.S. 82 (1937).

9432 StAT. 388,390 (1902), 43 U.S.C. $\$ \$ 372,383$ (1952).

95337 U.S. 682 (1949).

98199 F.2d 426 (10th Cir. 1952).

97 For text of $\S \S 7$ and 8 of this version see Hearings, supre note 4 , at 3 .

9866 STAT. 560 (1952), 43 U.S.C. § 666 (1952).

99 On February 25, 195\%, the Supreme Court in a per curiam decision, after two references to a Special Master, dismissed Texas' suit against New Mexico on the Rio Grande Compact because of the United States' indispensability. Texas v. New Mexico, 352 U.S. 991. The suit was commenced in 1951. The Department of Justice's refusal to intervene in that case tends to make interstate compacts a device which not only call for consent of Congress for their approval but consent of the Attorney General for their enforcement. The Attorney General has only his own conscience to guide him in the exercise of his discretion.

100 The 1956 Act authorizing the Colorado River Storage Project, 70 STAT. 110, 43 U.S.C. $\S 620 \mathrm{~m}$ (Supp. IV 1957) provides in $\$ 14:$ "In the operation and maintenance of all facilities, authorized by Federal law and under the jurisdiction and supervision of the Secretary of the Interior, in the basin of the Colorado River, the Secretary of the Interior is directed to comply with the applicable provisions of the Colorado River Compact, the Upper Colorado River Basin 
Without an adequate consent-to-suit provision, the Barrett Bill would prove a cruel and bitter disappointment. Many of the federal-state problems arise in the administration of reclamation projects where the United States is likely to be held an indispensable party. Without any means of enforcement, it is useless to confirm or establish legal riglits.

Objection has been expressed to the consent-to-suit provisions because they would have burdened the administration of federal projects. It is true that lawsuits are inconvenient, expensive, and sometimes unpredictable in result. They are, however, the only practical method of resolving legal controversies other than negotiation and compromise. The process of negotiation and conpromise is illusory when one party shields itself behind sovereign immunity-that great principle of public immorality that the king can do no wrong. Without an adequate consent-to-suit measure, the Barrett Bill and all bills of like purpose might better be left off the statute books.

The present remedy to redress federal-state grievances, public opinion, can be, as we know, an effective remedy. The adoption of the Barrett Bill, without an adequate provision for enforcement, miglit cripple, for a time, that reniedy. With all the enthusiasin for the Barrett Bill whicl now exists in the water counsels of the west, the effect of its passage would be for those concerned to breathe relief, and treat the problem as solved until experience proved the contrary.

\section{Constitutionality}

The constitutionality of the Barrett Bill would not require mention but for the fact that the Justice Department has expressed doubts. These seem of two kinds.

One challenge to constitutionality stems from a prohibition against the delegation of legislative power expressed in Knickerbocker Ice Co. v. Stewart, ${ }^{101}$ decided in 1920 . The Knickerbocker case is a five to four decision by Mr. Justice McReynolds holding unconstitutional a federal statute which attempted to give maritime tort claimant rights under state workmen's conpensation laws. The reason given for this holding was that incor-

Compact, the Boulder Canyon Project Act, the Boulder Canyon Project Adjustment Act, and the Treaty with the United Mexican States, in the storage and release of water from reservoirs in the Colorado River Basin. In the event of the failure of the Secretary of the Interior to so comply, any State of the Colorado River Basin may maintain an action in the Supreme Court of the Umited States to enforce the provisions of this section, and consent is given to the joinder of the United States as a party in such suit or suits, as a defendant or otherwise." Compare this provision with the holding in Miller v. Jennings, 243 F.2d 157 (5th Cir. 1957), cerl. denied, 26 U.SI. WeEx 3117 (U.S. Oct. 14, 1957) (No. 253), that the McCarran Act is inoperativo unless all persons who have rights are before the court. This limits the usefulness of the 1952 Act with respect to multi-state projects.

101253 U.S. 149 (1920). 
poration by reference of a state law in a federal statute unconstitutionally delegates Congress' power to state legislatures.

The Knickerbocker case is a relic from another constitutional era. It is perhaps good authority in admiralty, where congressional power is exclusive, but if it were to become a principle of general applicability, a constitutional amendment would be needed. The Bankruptcy Act, ${ }^{102}$ federal mining law, ${ }^{103}$ liquor law, ${ }^{104}$ and the Federal Rules of Civil Procedure ${ }^{108}$ have all based their operation on changing state laws without constitutional objection. So, for that matter, does section 8 of the Reclamation Act of 1902. ${ }^{108}$ The view which the Department of Justice takes of the Constitution would strait-jacket federal-state relationships essential to a healthy and workable federalism. ${ }^{107}$

The other objection rests on the implication of exclusive application of the federal property clause of the Constitution. Mr. Rankin concedes that Congress can dispose of federal property, but contends that it cannot retain title and delegate its management to the States. ${ }^{108}$ To this there are at least two good answers: First, there should be nothing constitutionally sacred about the assumption that unappropriated water is the property of the

102 E.g., § 70(e), 30 STAT. 566 (1898), 11 U.S.C. \$110(e) (1952).

103 E.g., Butte City Water Co. v. Baker, 196 U.S. 119 (1905). This case upheld Rev. STat. $\$ 2324$ (1875), 30 U.S.C. $\$ 28$ (1952), which provides that the miners of each mining district may make regulations, consistent with state and federal law, with respect to locating, recording, and working mining claims. The unsuccessful constitutional challenge to apphicability of a state statute was made on grounds almost identical to Justice Department representatives' attacks on constitutionality of the Barrett Bill.

104 E.g., Clark Distilling Co. v. Western Maryland Ry., 242 U.S. 311 (1917). Compare Griswold v. President of the United States, 82 F.2d 922 (5th Cir. 1936) (Connally "Hot Oil" Act upheld).

105 E.g., FED. R. CIv. P. 43 (a) (incorporating state court rules of evidence where more liberal than the federal rule). The constitutionality of federal incorporation of state rules of procedure is disposed of by Judge Learned Hand's opinion in Capital Co. v. Fox, 85 F.2d 97, 101-02 (2d Cir. 1936), cert. denied, 298 U.S. 672.

10832 STAT. 390 (1902), 43 U.S.C. $\$ \S 372,383$ (1952). Express recognition of state law in federal statutes dates from 1789. See 1 STar. 54 (1789), discussed in Cooley v. Board of Wardens, 53 U.S. (12 Wheat.) 299, 315 (1851).

107 This is a basic legal characteristic of the federal system succinctly summarized in an

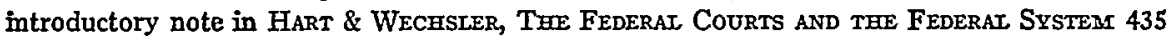
(1953): "Federal law is generally interstitial in its nature. It rarely occupies a legal field con1pletely, totally excluding all participation by the legal systems of the states. This was plainly true in the beginning when the federal legislative product (including the Constitution) was extremely small. It is significantly true today, despite the volume of Congressional enactments, and even within areas where Congress has been very active. Federal legislation, on the whole, has been conceived and drafted on an $a d$ hoc basis to accomplish limited objectives. It builds upon legal relationships established by the states, altering or supplanting them only so far as necessary for the special purpose. Congress acts, in short, against the background of the total corpus juris of the states in inuch the way that a state legislature acts against the background of the common law, assumed to govern unless changed by legislation."

108 Note 26 stupra. 
United States. More realistically, it is not property at all. Second, even assuming that unappropriated water is in some sense federal property, and that the Pelton Dam case made constitutional law, why cannot management of that property be delegated? The United States can turn over the Washington Monument grounds to the Boy Scouts as a camp site, delegating to them the supervision of the grounds. Is this unconstitutional? And if not, what is different about water?

Of the many reasonable differences of opinion about the Barrett Bill, in the writer's view constitutionality is not one.

\section{CONCLUSTON}

Whether the Barrett Bill becomes the Western Water Rights Settlement Act of 1957 (or 1958, 1959, or 1960) it has served a useful and desirable purpose in focusing attention not only on the basic ground rules under which water development proceeds, but on the source of those ground rules. ${ }^{109}$ To the extent that adequate respect has not been shown by federal officials for the policies of existing federal laws, as Senator Barrett and others have insisted, the prospect that the Barrett Bill will achieve the hoped for results is somewhat doubtful. The fault, perhaps, lies more with federal administration than with federal statutes; administration is a difficult matter for Congress to control.

The writer would prefer careful selection of the trouble spots, and legislation to deal with each as problems arise. One additional word of caution seems advisable. Both proponents and opponents of the bill are given to

109 The Barrett Bill problem will continue to arise in many contexts. For example, the current rivers and harbors and flood control bill which passed the Senate on March 28, 1957, S. 497, 103 Cong. Rec. 4133 daily ed., provides in section 205 (a), inter alia, that "storage may be included in any reservoir project to be constructed by the Corps of Engineers without reimbursement to increase low flows downstream to the extent warranted at that time, or anticipated to be warranted during the economic life of the project, by widespread, general, and nonexclusive benefits from such increases in low flow. . . "Reservoirs to be constructed by the Secretary of the Interior were likewise included. To this the Senate added an amendment by Senator Barrett: "Provided, That such storage be constructed and used in compliance with applicable State laws and interstate compacts: Provided further, That nothing herein shall bo construed to amend, modify, or limit, the applicability of section 8 of the Reclamation Act of 1902." For complete text see $\$ 205$ of S. 497, 85th Cong., 1st Sess., referred to House Committce on Public Works, March 29, 1957. 103 Covg. Rec. 4124-25 (Daily ed. 1957). The Senate debate on section 205 appears in 103 CoNG. Rec. 4096-97, 4104-08, 4119-25 (Daily ed. 1957):

"The House Public Works Committee in reporting S. 497 on August 13, 1957, deleted the Barrett amendment as well as the extension of authority to the Interior Department, retaining, however, the authority in the Corps of Engineers. The report notes the Barrett proviso to bo unnecessary because Corps of Engineers projects had been carried on for years 'without any question of interference with State laws or imterstate compacts. The committee believes that any specific proviso of this nature would either be unnecessary in some cases or unworkable in others. The committee notes that the Department of Justice agrees with this view?" (Emplasis added.) See H.R. REP. No. 1122, 85tll Cong., 1st Sess., p. 56 (1957). 
discussing it in constitutional terms. For example, Mr. Rankin has pointed out that the Barrett Bill would have made the Boulder Canyon Project, under which Hoover Dam was built on the Colorado, impossible in the light of the State of Arizona's vigorous objections. ${ }^{110}$

This misses an important point. The Barrett Bill would not become part of the Constitution. The Boulder Canyon Project was built as the result of a statute which had been the object of congressional concern through several Congresses. Most projects of comparable magnitude are the result of special legislation, tailored to a greater or lesser degree to the time, place, and occasion. This will continue to be so $\mathrm{m}$ the future with or without general legislation like the Barrett Bill. And general legislation will always yield to specific legislation of a later Congress applicable to a particular project. Delph Carpenter, distinguished water lawyer of Colorado, father of the Colorado River Compact, was as stout an advocate of unalloyed states' rights as the country has seen since Jefferson Davis. If living he would doubtless be a Barrett Bill enthusiast. Yet he was the author of the provisions of the Boulder Canyon Project Act which subjected the rights of every user of stored water in Hoover Dam to the terms of the Colorado River Compact, notwithstanding the bitter protests of the State of Arizona which had refused to ratify that Compact. ${ }^{111}$

If there is a lesson in this, it is an admomition against the doctrinaire, and against striving too hard for final settlement of a problem which refuses to yield to absolutes.

\section{APPENDIX I}

S. 863, 84th Cong., 1st Sess. (1955)

A BIIL

To govern the control, appropriation, use, and distribution of water.

Be it cracted by the Senate and House of Representatives of the United States of America in Congress assembled, That all of the navigable and unnavigable waters in the States enumerated in section 1 of the Reclamation Act of June 17, 1902 (32 Star. 388), and in the State of Texas, pursuant to the Act of February 25, 1905 (33 STar. 814), and the Act of June 12, 1906 (34 Srar. 259), are hereby declared free for appropriations under the jurisdiction of the State, and thereafter subject to the laws of that State with respect to control, use, and distribution of such appropriated waters for all beneficial uses.

Sec. 2. Federal officers, employees, agencies, and instrumentalities the same as private persons shall proceed in conformity with the laws of the State in which the appropriation has been or shall be instituted or perfected, and that each of them shall be governed by the laws of such State in respect to the control, use, and distribution of the appropriated water.

Sec. 3. The provisions of this Act shall not be construed as repealing or affecting any of

110 Hearings, stepra note 4, at 246-47; see Arizona v. California, 283 U.S. 423 (1931).

111 See Committee Print at pages 113-19, and Carpenter's testimony, pages 120-89, Hearings on H.R. 6251 and H.R. 9826 before the House Committee on Irrigation and Reclamation, 69th Cong., 1st Sess. (1926). This is the third Swing-Johnson Bill, in the Congress preceding the enactment of the fourth Swing-Johnson Bill as the Boulder Canyon Project Act, 45 STAT. 1057 (1928), 43 U.S.C. $\$ \S 617-17 t$ (1952). Current denunciations of the federal government's interference with state water rights are pallid by comparison to Carpenter's vigorous statement. 
the provisions of section 8 of the Reclamation Act, 1902, but shall be construed as being supplementary thereto.

\section{APPENDIX II}

\section{S. 863, 85th Cong., 1st Sess. (1957)}

A $B I T$

To affirm and recognize the water laws of the States lying wholly or partly west of the ninety-eighth meridian.

Be it enacted by the Senate and House of Representatives of the United States of America in Congress assembled, That this Act may be cited as the "Western Water Rights Settlement Act of 1957."

Sec. 2. In the arid and semiarid regions west of the ninety-eighth meridian rights to the use of water are property rights which are fundamental to the economic life and well-being of the American people. In view of the fact that the needs for water do not coincide with the location or the natural flow of the available sources of supply, it is recognized that rigbts to impound and divert water and to apply it to beneficial purposes, frequently at places substantial distances from the points of diversion or storage, are matters of paramount inportance. To promote the beneficial application of the available water supplies in these regions it is and has been necessary that public and nonpublic entities be encouraged to make investments in water resource developments. Security of right to the use of water for beneficial purposes is essential to such encouragement, and regulating the acquisition of water rights must be orderly and with full regard to the need for stability of such rights if public and private investments in water resource developments are to continue on a sound basis. Neither the proprietorship functions of the United States derived from the ownership of the public lands nor the exercise of its powers relating to interstate commerce and the general welfare should be permitted unduly to interfere with prior rights to the use of water or the orderly acquisition of such rights in the future. For more than ninety years this pohicy has been recognized by the Congress and the acquisition of such rights under State law has been encouraged and repeatedly protected by Federal legislation. Under this policy these States have been able to make their proper contribution to the strength of the Union, and twenty-seven million acres of arid and semiarid land have been brought under irrigation, of which only one-fourth are a result of federally assisted projects. It has not been and is not the intention of the Congress that Federal agencies, in pursuing their programs for water resources development in these arid and semiarid areas, shall have any prerogative to preempt the field or to cast clouds on the security of prior rights under State law acquired for beneficial purposes. Because of the fact that previous Acts of Congress have been and may be interpreted with respect to these States so as to cast clouds on such prior riglits and to interfere with the future orderly development of water resources in accordance with the foregoing declaration, it is the purpose of this Act: (1) to remove any such clouds; (2) to provide for the future acquisition of unappropriated ground and surface waters, navigable and nomavigable, in compliance with State laws; and (3) to provide adequate protections of the Federal interests to the end that the Federal Government may perform its functions in a manner consistent with the foregoing purposes.

Sec. 3. For the purposes of this Act-

(a) "Federal agency" means the executive departments and independent establishments of the United States, and corporations primarily acting as instrumentabities or agencies of the United States;

(b) "Employee of the Govermment" includes officers or employees of any Federal agency, members of the military or naval forces of the United States, and persons acting on behalf of any Federal agency in an official capacity whether temporarily or otherwise.

Sec. 4. This Act shall apply only to States lying wholly or in part west of the ninety-eighth meridian.

Sec. 5. In the use of ground and surface water for any purpose in connection with Federal programs, projects, or activities no Federal agency or employee of the Government shall inter- 
fere with the exercise of any right to the use of water for the beneficial purposes theretofore acquired under and recognized by State custom or law except when authorized by Federal law and upon payment of just compensation therefor: Provided, That the provisions of this Act shall not be construed to preclude, when authorized by Federal law, the acquisition by or for the Umited States of such rights by purchase, exchange, gift, or eminent domain, or by any manner of acquisition recognized under State law.

Sec. 6. Subject to existing rights, all unappropriated navigable and nonnavigable ground and surface waters are reserved for appropriation and use of the public pursuant to State law, and rights to the use of such waters for beneficial purposes shall be acquired under State laws relating to the appropriation, control, use, and distribution of such waters. Federal agencies and permittees, licensees, and employees of the Government, in the use of water for any purpose in connection with Federal programs, projects, activities, licenses, or permits, shall acquire rights to the use thereof in conformity with State laws and procedures relating to the control, appropriation, use, or distribution of such water: Provided, That nothing in this Act shall be construed to require the acquisition by the Umited States of such rights in the storage and release of water by the United States solely for the prevention of fioods: Provided further, That the United States may acquire such rights, when authorized under Federal law, by purchase, exchange, gift, or eminent domain: Provided further, That no right hereafter acquired under State law shall be enforceable against the Umited States if such right would be enforceable against the United States only because of a State law or custom which discriminates against the United States or denies the United States the opportunity to acquire such rights on terms and conditions at least as favorable as those under which any other entity or person may acquire such rights: And provided further, That nothing in this Act shall be construed to permit any person or entity to acquire the right to store or divert waters in any national park or monument unless otherwise authorized by Act of Congress.

Sec. 7. Nothing in this Act shall be construed to unpair or diminish the rights of any State or the United States to waters under any interstate compact or judicial decree, or to permit appropriations of water under State law which interfere with the fulfillment of treaty obligations of the United States, or to affect, impair, diminish, or enlarge any existing water rights in Indians, Indian tribes, or persons claiming under or through them or any Federal reclamation project heretofore authorized by the United States.

Sec. 8. Subject to existing rights the use for navigation of waters arising in States lying wholly or partly west of the ninety-eighth meridian shall be only such use as does not confilict with any beneficial use thereof, present or future, in States lying wholly or partly west of the ninety-eighth meridian, of such waters for domestic, municipal, stock water, irrigation, mining, or industrial purposes.

Sec. 9. All withdrawals and reservations of public land heretofore or hereafter made by the United States shall be deemed made without prejudice to the beneficial use of water originating in or fiowing across such lands, theretofore, or thereafter initiated under the laws of the States in which such lands are situated.

Sec. 10. The provisions of this Act shall not be construed as repealing or affecting any of the provisions of section 8 of the Reclamation Act of 1902, but shall be construed as being supplementary thereto.

Sec. 11. Any license or permit issued under the Federal Power Act for the construction of any project works (as defined in such Act), which would impound or divert or interrupt the fiow of nonnavigable and intrastate waters, is hereby suspended if such construction has not on the date of enactment of this Act reached a stage of completion which effects such impounding, diversion, or interruption. Any suspension under the provisions of this Act may be terminated by the Federal Power Commission upon a determination by the Commission that all requirements of this Act have been substantially complied with by the licensee or permittee whose license or permit is suspended.

Sec. 12. If any provision of this Act or the applieation of such provision to any person, organization, or circumstance shall be held invalid, the remainder of the Act and the application of such provision to persons, organizations, or circumstances other than those as to which it is held invalid shall not be affected thereby. 